\title{
ANALISIS PENGGUNAAN DIKSI DAN POLA BERITA HOAKS PADA WHATSAPP
}

\section{ANALYSIS OF THE USE OF DIKSI AND HOAX NEWS PATTERNS ON WHATSAPP}

\author{
${ }^{1}$ Alfi Sailin Ni'mah, ${ }^{2}$ Itaristanti, ${ }^{3}$ Indriya Mulyaningsih \\ ${ }^{1,2,3}$ IAIN Syekh Nurjati Cirebon \\ ${ }^{1}$ sailinnimah@gmail.com, ${ }^{2}$ itaristanti@gmail.com, ${ }^{3}$ indriya.m@gmail.com
}

\begin{abstract}
Abstrak
Penelitian penggunaan diksi dan pola berita ini difokuskan pada berita hoaks Desember 2018 sampai Februari 2019. Berita hoaks dalam penelitian ini berupa informasi yang di sebarkan oleh idividual, tetapi telah dilaporkan dan di verifikasi oleh kominfo. Indikator bahwa berita itu merupakan berita hoaks adalah atas hasil ketetapan Kominfo.Metode yang digunakan pada tahap pengumpulan data atau penyediaan data adalah metode simak teknik lanjutan teknik teknik bebas libat cakap. Penelitian ini menggunakan pendekatan kualitatif dengan tipe deskriptif. Metode yang digunakan dalam menganalisis data adalah metode agih dan padan. Hasil penelitian ini dapat disimpulkan bahwa penggunaan diksi dalam berita hoaks pada WhatsApp dalam kurun waktu Desember 2018 sampai Februari 2019 ditemukan penggunaan diksi bahasa asing, bahasa daerah, ragam cakapan, dan singkatan kata yang tidak sesuai KBBI. Berdasarkan 21 berita tidak semua ditemukan pola $5 \mathrm{~W} 1 \mathrm{H}$ + so what. Ada beberapa berita yang hanya terdiri dari unsur apa, siapa, dan di mana. Ada beberapa berita pula yang tidak dilengkapi hanya salah satu unsur $5 \mathrm{~W} 1 \mathrm{H}$ tersebut.Namun, mayoritas dari 21 berita hoaks ini memiliki unsur so what berupa kalimat imperatif. Ketidaklengkapan unsur $5 \mathrm{~W} 1 \mathrm{H}$ dalam berita menyebabkan sebuah berita kurang akurat kebenarannya dan kalimat imperatif sebagai unsur so what itulah penyebab berita yang belum diketahui kebenarannya akan tersebar dengan mudah. Kata Kunci: diksi, pola berita, berita hoaks
\end{abstract}

\begin{abstract}
The indicator that the news is news hoaks is based on the results of the Ministry of Communication and Information. The method used at the stage of data collection or data provision is a method of referring to advanced techniques of competent free-involvement techniques. This research uses a qualitative approach with descriptive type. The method used in analyzing data is the method of distribution and matching. The results of this study can be concluded that the use of diction in hoax news on Whats App in the period December 2018 to February 2019 found the use of foreign language dictionaries, regional languages, variety of skills, and word abbreviations that are not in accordance with KBBI. Based on 21 news not all patterns were found $5 \mathrm{~W} 1 \mathrm{H}+$ so what. There are some news which only consists of what elements, who and where. There is also some news which is not equipped with only one of the $5 \mathrm{~W} 1 \mathrm{H}$ elements. However, the majority of these 21 news hoaks have an element of what is in the form of imperative sentences. The incompleteness of the $5 \mathrm{~W} 1 \mathrm{H}$ element in the news causes a news to be inaccurate and the imperative sentence as an element of so what is the cause of the news whose truth is not yet known will spread easily.
\end{abstract}

Keywords: diction, news patterns, hoaks news

\section{PENDAHULUAN}

Beberapa tahun terakhir dunia jurnalistik mendapat istilah baru. Istilah tersebut menjadi salah satu gangguan bagi para jurnalis yang notabene bertugas mencari dan mempublikasikan berita. Istilah tersebut adalah sebutan bagi berita palsu atau bohong yang direncanakan dalam proses pembuatan maupun penyebarannya. Masyarakat umum mengenal istilah tersebut dengan berita hoaks. 
Istilah hoaks mulai terkenal pada tahun 2005 ketika film The Hoaks beredar. Menurut Rusdi (2018: 138) hoaks justru lebih dari sekadar berita bohong. Hoaks adalah informasi yang sengaja dibuat untuk menipu atau mengelabui orang banyak. Tidak jarang pula, berita hoaks disertai dengan fakta dan data, sehingga banyak masyarakat langsung percaya begitu saja tanpa menelaah lebih dalam.

Dewasa ini, masyarakat berlomba-lomba mengejar informasi agar tidak dianggap ketinggalan zaman. Informasi sudah menjadi barang dagangan. Tidak hanya itu, masyarakat menjadi sangat terbuka terhadap informasi apa pun, mulai dari ekonomi, politik, sosial, bahkan gaya hidup. Di era seperti ini, media massa menjadi media yang sangat berpengaruh dalam kehidupan, sebab seluruh hierarki masyarakat akan selalu mencari berita sebagai informasi yang sudah menjadi makanan pokok tiap hari.

Tidak ada lagi jarak jauh yang menjadi sekat, justru dunia menjadi terasa sangat sempit sejak internet berkembang. Mulai dari surat-menyurat, jual beli, bahkan, makanan pun sekarang sudah tinggal pesan saja melalui internet. Para wartawan kini kian terampil dalam mencari dan meramu berita. Namun negatifnya, berita sudah tidak lagi berisi fakta. Banyak berita yang telah diisi dengan opini dari wartawan, baik dari sisi judul maupun isi berita itu sendiri.

Menurut Willing Barus (2010: 11) berita adalah laporan peristiwa, kejadian, atau kenyataan yang menarik untuk disampaikan kepada masyarakat melalui media massa. Berita adalah sebuah laporan peristiwa, tetapi laporan belum tentu berita. Suatu laporan baru disebut berita jika laporan tersebut dinaikkan dan dibaca oleh publik. Oleh karena itu, berita memiliki syarat dan kriteria dalam bahasa yang disampaikan, baik melalui tulisan maupun lisan.

Maraknya berita hoaks di kalangan media sosial berdampak negatif, seperti hoaks tentang penculikan anak di November 2018. Banyak berita yang menyebar tentang penculikan anak dengan disertai foto dan video. Berita-berita penculikan anak tersebut disebar melalui media sosial, baik Facebook, WhatsApp, Twitter, maupun Instagram. Berita penculikan anak ini sangat meresahkan warga, terlebih para ibu rumah tangga yang memiliki anak kecil. Namun, setelah ditelusuri oleh Badan Reserse Kriminal (Bareskim), berita tersebut dinyatakan hoaks dan Bareskim telah berhasil menangkap enam pelaku sebagai penyebar hoaks di Facebook. Akibat dari berita hoaks penculikan anak tersebut menjadikan orang tua tidak membiarkan anak-anak bermain dengan tenang.Berita tersebut juga menjadikan orang tua trauma.Padahal sejatinya anak-anak sangat membutuhkan waktu bermain dan bersosial dengan kawan sebaya agar lebih menjadi generasi yang cerdas dalam sosial dan berani menghadapi rasa takut.

Kecepatan informasi di media massa konvensional tampak sudah tergantikan oleh peranan media sosial dalam menyebarkan berita. Namun, dengan adanya kecepatan yang tak terbatas ini fungsi berita yang seharusnya menjadi kontrol sosial justru mendapatkan citra yang buruk. Dewasa ini, semua orang bisa menulis berita. Istilah jurnalistik bagi jurnalisme warga (warga yang menulis berita) adalah citizen journalizm. Hal ini mengakibatkan banyak pula berita yang tersebar bukan hasil temuan wartawan yang berada di naungan media atau badan 
hukum. Namun, banyak masyarakat lain yang menggunakan kesempatan ini untuk menyebarkan berita bertujuan menumbuhkan citra negatif orang-orang tertentu.

Berita hoaks sangat mudah tersebar, terlebih di media sosial seperti Whats App. Pertiwi (2018: 1) dalam artikel di Kompas Tekno berhasil merangkum penelitian We Are Social dari perusahaaan milik Negara Inggris yang bekerja sama dengan Hootsuite. Rangkuman penelitian itu diketahui bahwa penggunaan media sosial Facebook menempati angka 41 persen, 40 persen menggunakan Whats App, dan 38 persen pengakses Instagram di Indonesia pada tahun 2018. Berdasarkan penelitian yang dilakukan Ruri Rosmalinda (dalam Marwan \& Ahyad, 2018: 3) tentang "Fenomena Penyesatan Berita di Media Sosial" menyatakan bahwa penyebaran berita hoaks dapat menjadi ancaman teknologi secara global, khususnya di Indonesia.

Whats $A p p$ telah menjadi aplikasi yang diminati di kalangan remaja dan dewasa. Hal ini menjadikan penyebaran berita hoaks di Whats $A p p$ mudah sekali tersebar. Penelitian ini berjudul "Analisis penggunaan diksi dan pola berita hoaks pada WhatsApp", sebab WhatAspp mengunggulkan percakapan secara personal dan grup, sehingga penyebaran berita akan langsung sampai kepada pemilik akun. Analisis ini berlandaskan pada teori Hymes, A. Teun Van Dijk, dan Pedoman Umum Ejaan Bahasa Indonesia. Penelitian ini bertujuan agar masyarakat cerdas dan cermat dalam menerima berita dengan dibekali ciri-ciri pola berita hoaks pada Whats App.

\section{METODE}

Sumber data penelitian ini termasuk ke dalam sumber tertulis, sebab berita diperoleh dari sumber tertulis di Whats App yang telah diverifikasi oleh Kementerian Komunikasi dan Informasi (Kemen Kominfo) bahwa berita tersebut hoaks. Berita yang telah diverifikasi oleh Kominfo merupakan kumpulan berita yang dilaporkan oleh masyarakat dalam bentuk salin - tangkap yang tidak dijelaskan proses penyebarannya. Subjek penelitian berupa berita-berita hoaks yang ditemukan di akun media sosial WhatsApp. Adapun objek penelitian berupa bahasa yang digunakan dalam berita hoaks dan ciri-ciri dari akun media sosial Whats App yang kemudian dicari pola kekhasan dari berita hoaks di Whats App.

Metode yang digunakan pada tahap pengumpulan data atau penyediaan data adalah metode simak teknik lanjutan dan teknik bebas libat cakap. Teknik simak adalah teknik yang dilakukan dengan cara menyimak penggunaan bahasa. Penelitian ini menggunakan pendekatan kualitatif dengan tipe deskriptif yang lebih mengedepankan penggambaran tentang suatu fenomena ketepatan penggunaan diksi dan pola dalam teks berita hoaks. Metode yang digunakan dalam menganalisis data adalah metode agih. Metode agih adalah metode analisis yang alat penentunya terdapat di dalam dan merupakan bagian dari bahasa yang diteliti dan metode padan adalah metode analisis yang alat penentunya terdapat di luar dari bahasa yang diteliti. 


\section{HASIL DAN PEMBAHASAN}

\section{A. Diksi berita hoaks}

Terdapat tiga bahasa asing yang digunakan dalam berita hoaks pada Whats $A p p$. Istilah atau kosakata bahasa asing adalah bahasa selain bahasa Indonesia yang digunakan dalam penyampaian berita. Kosakata bahasa asing tersebut hanya muncul beberapa kata dalam suatu berita hoaks. Biasanya penggunaan diksi bahasa asing bertujuan memberikan kesan megah atau gagah suatu kalimat. Padahal adanya pilihan bahasa asing yang tersisipi dalam berita yang notabene berbahasa Indonesia hanya akan merugikan perkembangan bahasa Indonesia.

Tidak hanya terdapat bahasa asing, diksi bahasa daerah pun ditemukan dalam beberapa berita hoaks pada Whats App. Penggunaan kosakata bahasa daerah biasanya menandakan asal penulis atau penyebar berita hoaks. Hal ini pula yang mencari salah satu ciri khas bahwa penulis berita menulis tidak untuk keadaam resmi. Multilingual terjadi karena penulis menguasai lebih dari satu bahasa.

Bahasa yang digunakan dalam berita hoaks pada Whats $A p p$ adalah bahasa Indonesia. Namun, ditemukan beberapa diksi yang menggunakan istilah asing dan kosa kata bahasa daerah. Padahal, padanan diksi bahasa asing atau diksi bahasa daerah tersebut ada di dalam pembendaharaan kata bahasa Indonesia. Suatu perubahan atau peralihan bahasa atau kode dikarenakan situasi tertentu dalam kegiatan berbahasa merupakan bentuk campur kode atau alih kode.

\section{Campur kode}

Campur kode adalah memasukkan unsur bahasa lain dalam bahasa utama yang sedang digunakan. Ketika seseorang sedang berkomunikasi dengan orang lain menggunakan bahasa Indonesia kemudian orang tersebut menyisipkan satu kata dari bahasa Jawa, maka itulah campur kode. Campur kode tidak berlaku untuk bahasa Indonesia saja, tetapi untuk seluruh bahasa.

a. Bahasa Inggris

Terdapat 30 kosakata bahasa Inggris yang ditemukan dalam 52 berita hoaks pada WhatsApp. Berikut penjelasan mengenai contoh penggunaan campur kode bahasa Indonesia dengan bahasa Inggris.

1) Share ke smua sosmed biar saudara2 muslim kita tau

(Share ke semua sosial media agar saudara-saudara muslim kita tahu)

2) Contact Person Tb. H. Rifqi, Lc. (085 799321 000)

3) Layaknya film2 action

(Layaknya film-film action)

Kata share dan contact person merupakan kosakata bahasa Inggris yang disisipkan dalam penulisan berita dengan bahasa utama bahasa Indonesia. Penggunaan kosakata bahasa Inggris dalam proses campur kode bertujuan agar berita terlihat berwibawa. Kata 
yang dipilih pun sebenarnya merupakan kata yang sering digunakan dalam kasus campur kode secara lisan.

Kata share memiliki terjemah dalam bahasa Indonesia, yaitu bagikan. Dalam kaidah kebahasaan, terdapat syarat dan proses tertentu untuk mengubah istilah asing menjadi bahasa Indonesia. Proses tersebut yaitu penerjemahan, pengadopsian, dan adaptasi. Kata share memiliki padanan kata dalam bahasa Indonesia, yaitu bagikan.

Kata contact person mempunyai arti narahubung atau orang yang dapat dihubungi. Penerjemahan bahasa asing ke dalam bahasa Indonesia terdapat beberapa jenis, di antaranya bentuk hasil kata yang diterjemahkan menjadi bentuk yang sama atau berbeda. Misalkan awal kata share diterjemahkan menjadi kata bagikan, maka kasus tersebut merupakan proses terjemah dalam bentuk sama. Kata contact person diartikan dalam bahasa Indonesia menjadi kata narahubung. Hal ini menjadi contoh kasus proses padanan kata asing ke dalam bahasa Indonesia dari segi penerjemahan secara bentuk yang berbeda. pasalnya, kata contact person terdiri dari dua bentuk kata, sedangkan kata narahubung terdiri dari satu kata.

b. Bahasa Jawa

Terdapat kosakata matur sumun yang ditemukan di salah satu 52 berita hoaks pada Whats App. Matur nuwun bermakna terima kasih, akan tetapi tingkat tutur yang dimiliki kata ini berada dalam tingkatan tertinggi. Campur kode tidak hanya terjadi pada perubahan bahasa satu ke bahasa lainnya, tetapi juga akan dianggap campur kode jika perubahan kode terjadi pada tingkat tutur dalam sebuah bahasa. Tingkat tutur terbagi menjadi tiga di dalam bahasa Jawa, yaitu ngoko, madya, dan paling tinggi adalah kromo.

Contoh kalimat matur suwun sababat semua. Kata matur sumun dalam kalimat tersebut jelas memiliki nilai rasa yang tinggi atau berarti menghormati. Hal itu tergambarkan bahwa penulis menghargai pembaca yang dianggap sebagai sahabatnya. Dikarenakan tingkat tutur kata matur sunun adalah kromo atau paling tinggi, penulis memilih diksi itu sebagai bentuk penghormatan.

2. Alih kode

Perbedaan campur kode dan alih kode adalah dari segi banyak tidaknya bahasa campuran yang digunakan. Campur kode terjadi pada tataran kata dan frasa, sedangkan alih kode terjadi pada tataran klausa ke atas. Alih kode terjadi jika penutur menggunakan bahasa utama berupa bahasa Indonesia, kemudian berpindah menggunakan bahasa sunda dalam satu kalimat atau lebih. Penyebab terjadi alih kode bisa karena penutur, pendengar, bahasa yang digunakan, atau bahkan situasi.

Terdapat beberapa kali alih kode yang ditemukan di dalam 52 berita hoaks pada Whats App, baik berupa bahasa asing maupun bahasa daerah. Berikut ini adalah penjelasan alih kode yang terdapat pada data. 
a. Bahasa Inggris

Tertulis kalimat This video must be seen by everyone. This video has been taken by Dr. Harish Shukla of Apollo pada berita ke 40. Keseluruhan berita tersebut menggunakan bahasa Indonesia, tetapi terdapat penggunaan bahasa Inggris di bagian akhir berita.Kalimat tersebut bermakna video ini harus dilihat setiap orang. Video ini diambil oleh Dr. Harish Shukla dari Apollo. Peralihan bahasa yang terjadi bukanlah campur kode, karena berupa rangkaian kata yang terstruktur.

b. Bahasa Arab

Terdapat satu kalimat bahasa Arab dalam berita yang berbeda.berikut ini adalah data dan penjelasan alih kode yang terjadi antara bahasa Indonesia dan bahasa Arab. Jazakumullah khoyron jika diterjemahkan ke dalam bahasa Indonesia yaitu semoga Allah akan memberi balasan baik kepadamu. Seperti pada penggalan berita di bawah ini.

...

Pendaftaran terakbir Desember 2017. Seleksi imam bln Januari di Kemenag Pusat.

Pusat informasi:

Direktur Penerangan Agama Islam (Penais) kemenag RI Pusat Dr. H.Khoeruddin Ilyas, M.M.

Mohon bantu share. Jazakumullabu khoiron.

Kalimat tersebut merupakan kalimat balasan dari sebuah kebaikan yang telah orang lain lakukan. Kalimat berupa doa agar Allah membalas hal baik yang serupa kepada pelaku kebaikan. Perubahan bahasa terjadi tidak hanya pada satu kata, namun dalam satu kalimat. Hal itu disimpulkan bahwa dalam berita ketiga terdapat alih kode dari bahasa Indonesia ke bahasa Arab.

c. Bahasa Sunda

Peralihan kode atau bahasa tidak hanya terjadi dari bahasa Indonesia ke bahasa asing, akan tetapi juga terjadi pada bahasa daerah.

...

Mulai sekarang biasakan merebus air $1 \times$ saja.

Kmb tah Teh Lulu?

Sebuah kalimat sunda ditemukan dalam sebuah berita hoaks yang ada pada Whats $A p p$. Kalimat itu tertulis Kmb tab teh Lulu? atau seharusnya ditulis dengan Kumaha tah teh Lulu? Kalimat tersebut memiliki makna bagaimana itu Kak Lulu?

Bahasa utama pada berita tersebut adalah bahasa Indonesia. Isi berita tersebut adalah bahaya merebus air yang telah mendidih sebelumnya. Seluruh berita menggunakan bahasa Indonesia, tetapi di akhir terdapat sebuah kalimat tanya menggunakan bahasa Sunda. Hal ini merupakan bagian dari kasus alih kode. 
3. Analisis Wacana Van Dijk

Analisis Wacana Van Dijk merupakan teori yang merupakan terori wacana yang biasanya digunakan untuk menganalisis berita.Proses pembuatan berita terdiri dari teks, kognisi sosial, dan analisis sosial. Namun dalam hal ini akan dibahas teks yang menjadi kerangka nyata sebuah berita hoaks.

Teks dalam kajian analisis wacana Van Dijk terdiri dari lima belas bagian. Berikut ini lima belas bagian teks yang akan menjadi kerangka dalam analisis teks berita hoaks pada WhatsApp.

a. Tematik

Tematik atau biasa disebut tema merupakan bahasan inti dari sebuah berita.Setiap berita memiliki tema.Begitu pula dengan dua puluh satu berita hoaks yang dianalisis. Berita (1) memiliki tema peringatan bencana alam, berita (2) dan berita (13) bertema binatang berbahaya, berita (3) dan berita (11) bertema informasi lowongan kerja, berita (4) bertema pemberian hadiah, berita (5) dan berita (14) bertema bahasa virus dan radiasi telepon genggam, berita (6), berita (12) dan berita (19) bertema klarifikasi, berita (7) bertema mengisi baterai secara instan, berita (8) dan berita (10) bertema penipuan, berita (9) bertema pengesahan UU LGBT, berita (15) bertema prabowo stroke, berita (16) bertema tenggat pembayaran listrik dimajukan, berita (17) dan berita (18) bertema bahaya makanan, berita (20) bertema penculikan, dan berita (21) bertema bahaya komunis.

\section{b. Skematik}

Skematik berita terdiri dari dua bagian, yaitu summary yang terdiri dari judul dan lead, dan story yang terdiri dari isi berita secara keseluruhan dan komentar narasumber.

Berita (1) tidak memiliki judul berita, hanya tertulis kata pengumuman.Berita (2) tidak memiliki judul berita, tetapi tertulis kalimat ïinsekedar informasi. Berita (3) tidak memiliki judul berita, tertulis asslm..wr. wh. Berita (4) tertulis judul Hadiah Natal Whats.App.Berita (5) berjudul Hari iniradio berbicara tentang Whats App Gold dan itu benar.Berita (6) (7) (9) tidak berjudul.Berita (8) tidak berjudul, tertulis assalamualaikum wrwb. Berita (10) tidak berjudul, tetapi tertulis $W$ a dari Bpk Kapolda.

Berita (16) tidak ada judul. Berita (17) berjudul merebus air yang sudah mendidih termyata berbahaya!Berita (18) tidak berjudul, tetapi diawali dengan kalimat Video ini harus dilibat oleh setip orang.Kata setip adalah bentuk salah penulisan dari kata setiap. Berita (19) tidak berjudul, tetapi diawali dengan kata astagfirlob!! Penulisan baku kata astagfirloh yaitu astagfirullabal-azim. Berita (20) tidak berjudul, hanya diawali kata viralkan...!!!Berita (21) tidak berjudul, hanya diawali kata info penting.

c. Latar

Latar merupakan bagian yang menjelaskan sesuatu yang ingin ditampilkan oleh penulis berita. Adanya penjelasan latar akan menggiring pemahaman pembaca terhadap arah suatu berita. Berita (1) latar yang disampaikan dalam berita (1) yaitu agar warga 
Cilegon, Serang, dan Bandar Lampung waspada terhadap prediksi tsunami dari BMKG.Berita (2) disertai sumber Entomolog kesehatan dari Kementerian Kesehatan RI sehingga meyakinkan pembaca bahwa gigitan binatang tersebut dapat menyebabkan kematian. Berita (3) lowongan kerja imam masjid disertai informasi berpusat dari Direktur Penerangan Agama Islam Kementerian Agama RI Pusat atas nama Dr.H. Khoiruddin Ilyas, M.M. Berita (4) terdapat akses laman untuk mendapatkan hadiah $35 \mathrm{~Gb}$ dari WhatsApp.

Berita (5) terdapat kalimat jika Anda menerima pesan untuk memperbarui Whats App Gold, jangan dibuka.Kalimat tersebut merupakan kalimat yang mendukung berita Virus Martinelli yang diberitakan di dalam berita (5). Terdapat kalimat coba kalian bayangin, berapa milyar gereja perbulan dapat dari ribuan Indomaret (mungkin super/minimarket lain) dalam berita (6) menjadi kalimat yang membuat pembaca akan mengira-ngira pendapatan gereja dari sumbangan minimarket, padahal tidak ada saksi dan bukti autentik akan hal tersebut. Latar berita (7) adalah kalimat ni magic betul. Serius yang seakan-akan berita ini sudah terbukti benar.Terlebih terdapat kalimat ajakan untuk mencoba saran yang diberitakan.

Latar berita (16) adalah pembayaran sesudah tanggal yang ditentukan, akan dikenakan denda. Berita (17) ditemukan latar belakang yaitu berupa penjelasan bahanbahan kima yang terkandung dalam air matang yang direbus kembali.Latar berita (18) adalah terdapat video yang memperlihatkan cacing di dalam usus.Berita (19) terdapat kalimat kalian sedang diyahudinisasi yang menjadi bukti bahwa penulis mendukung berita tersebut.Latar pada berita (20) adalah warga asing dari Cina tidak aman akibat sekelompok orang bersenjata tajam.Latar berita (21) yaitu terdapat orang yang menjebak pengguna mobil dengan menempelkan stiker berlogo PKI.

d. Detil

Detil merupakan bentuk ekpresi penulis berita yang dituangkan secara implisit. Tidak semua berita yang ditemukan menyajikan detil. Berikut ini adalah pembahasan detil terhadap berita hoaks yang ada di Whats App.

Detil berita (2) adalah kalimat orang yang terkena gigitan binatang itu. penulis berita tidak menyebutkan nama binatang yang dimaksud. Kalimat GKI katanya merupakan detil berita (6). Detil berita (7) adalah kata pelajar universiti, tanpa menjelaskan nama universiti tertentu. Kalimat tidak dipublikasikan pak sengaja takut dikonfrontasi merupakan detil berita (9). Detil berita (12) adalah kalimat telah dibagikan Alquran palsu ke sekolah-sekolah dengan dalih wakaf Alquran. Tanpa menyebutkan bukti sekolah yang jelas terindikasi menerima Alquran dengan tafsir palsu.

\section{e. Maksud}

Maksud dalam berita merupakan ekspresi penulis berita yang dijelaskan secara eksplisit dan jelas. Karena maksud adalah lawan dari detil, maka berita yang tidak disebutkan dalam pembahasan detil menjadi berita yang akan dibahas dalam pembahasan maksud. Berikut adalah analisis maksud. 
Salah satu maksud berita (10) adalah kalimat baru-baru ini ditemukan paket narkoba berupa $1 \mathrm{~kg}$ Metaphetamin dalam tas yang dikirim ke Magelang dari Thailand dengan modus salah kirim. Maksud berita ke- (11) adalah kalimat laki-laki usia 25-35 tahun. Kalimat sekedar info mulai bulan Maret pembayaran tagihan PLN dimajukan tanggal 5 merupakan maksud berita (16).Kalimat yang menjadi maksud berita (17) adalah kalimat Flaouride yang ditemukan dalam air minum mengakibatkan rendahnya IQ pada anak-anak. Maksud yang ditemukan dari berita (19) adalah kalimat saya baru sadar bahwa arti dari om telolet om adalah saya yabudi.

\section{f. Koherensi}

Bagian keenam dari rangkaian analisis wacana dari Van Dijk yaitu koherensi.Kohorensi adalah kesinambungan antarkata atau antarkalimat dalam sebuah teks.Anak kalimat dan induk kalimat yang bisa dipadukan dengan menggunakan elemen kohorensi.Koherensi di sini dibagi menjadi dua, yaitu koherensi kondisional dan koherensi pembeda. Hal yang membedakan antara koherensi kondirional dan pembeda adalah ketika dua kalimat yang menjadi induk kalimat dan anak kalimat dapat dihubungkan atau bahkan dibedakan satu sama lainnya. Berikut ini adalah analisis koheren dalam berita hoaks.

Terdapat kalimat yang menjelaskan koherensi kondisional dan koherensi pembeda dalam berita (6). Koherensi kondisional ditandai dengan kata terus, kata karena dua kali, seperti pada salah satu sampel kalimat saya yakin banyak yang tidak tabu bal ini karena tidak detail nanya. Kalimat tersebut menggunakan kata karena sebagai penghubung antara dua kalimat.Kemudian terdapat kalimat tapi dia iseng bercandanya merupakan kalimat koherensi pembeda, sebab menggunakan kata tapi sebagai ciri kalimat koherensi pembeda.

Hanya ditemukan kalimat kherensi kondisional dalam berita (7) yang ditunjukkan dengan kata dan dalam kalimat coba kirim ke 4 grup dan bettery anda akan penub. Terdapat koherensi kondisional dan pembeda.Koherensi kondisional ditunjukkan dengan kata dengan, kata dan dua kali, habis atau bermakna setelah, setelah, dan karena, sedangkan koherensi pembeda ditemukan menggunakan dua kali kata atau dan satu kata tapi. Salah satu sampel kalimat koherensi dalam berita (8) adalah benar saja, ada seseorang dengan fasilitas BRI mobile yang mengambil tabungan dia 2 jam setelab dia mereply sms pagi tadi.

Hanya terdapat koherensi kondisional dalam berita (9) yang dicirikan dengan menggunakan kata dan sebagai penghubung antara dua kata, yaitu dalam kalimat ternyata PPP dan PKB ikut mendukung.Ditemukan koherensi kondisional yang ditunjukkan dengan penggunaan kata dan, lalu, agar, dan kata dengan tertulis sebanyak tiga kali dalam berita (10).Salah satu kalimat yang menunjukkan koherensi kondisional tersebut adalah mereka lalu akan datang dengan menyamar sebagai petugas. Ditemukan dua kalimat koherensi kondisional yang menggunakan kata dan sebagai tanda koherensi kondisional dalam berita (11).

Ditemukan dua kalimat koherensi kondisional dalam berita (12).Kalimat pertama menggunakan kata dengan, sedangkan kalimat kedua menggunakan kata biar yang bermakna menunjukkan tujuan. Terdapat kalimat koherensi kondisional dalam berita (13) yang dicirikan dengan penggunaan kata dengan.Kalimat lainnya menggunakan kata dan, 
bahkan terdapat empat kalimat.Terdapat dua kalimat koherensi kondisional yaitu jagung bisa menjadi popcorn dengan radiasi dan gelombang handphone.Dalam kalimat tersebut, terdapat kata dengan dan kata dan sebagai ciri kondisional.Ditemukan pula koherensi pembeda dengan ciri kata atau dalam kalimat saat anake anda tidur atau ketika mau tidur.Berita (15) tidak ditemukan kalimat koherensi.

\section{g. Pengingkaran}

Pengingkaran adalah bentuk penulisan yang menggambarkan ekspresi penulis berita secara implisit.Pengingkaran merupakan hasil pengolahan kalimat oleh seorang penulis yang sebenarnya penulis tidak setuju dengan fakta yang ada.Setelah dicari dan dianalisis, dari seluruh data berita hoaks yang diperoleh, tidak ada berita yang mengandung kalimat pengingkaran.

\section{h. Bentuk kalimat}

Bentuk kalimat merupakan pemaparan dari kalimat secara sintaksis dan semantik.Contoh kalimat penyumbatandi usus karena konsumsimie atau spageti yang disingkirkansaat dokter melakukan operasi, sangat menakutkan pada berita (18). Jika dikelompokkan sesuai fungsi kata dalam sebuah kalimat, penyumbatan merupakan predikat, di usus adalah keterangan tempat, kata karena sebagai pemisah antara induk kalimat dan anak kalimat, konsumsi adalah predikat, mie atau spageti adalah objek, disingkirkan merupakan kata kerja yang menjadi keterangan perbuatan, saat dokter melakukan operasi adalah keterangan waktu, dan sangat menakutkan merupakan keterangan sifat.

Kalimat tersebut tidak sesuai kaidah gramatikal, sebab tidak adanya subjek, sedangkan syarat minimal kalimat adalah gabungan kata minimal terdiri dari subjek dan predikat.Setidaknya harus ditulis menjadi penyumbatan usus disebabkan karena seseorang mengonsumsi mie dan spageti.Mie dan spageti disingkirkan dokter saat melakukan operasi.Sangat menakutkan.Penyumbatan usus menjadi subjek, disebabkan menjadi predikan pasif, karena menjadi kata hubung antara induk kalimat dan anak kalimat, seseorang menjadi subjek, mengonsumsi menjadi predikat, mie danspageti menjadi objek.

Kemudian kalimat kedua, yaitu mie dan spageti disingkirkan dokter saat melakukan operasi.Mie dan spageti menjadi objek, disingkirkan menjadi predikat bentuk pasif, dokter merupakan subjek, dan saat melakukan operasi merupakan keterangan perbuatan.Kalimat ini disebut kalimat pasif, karena menempatkan objek di awal kalimat dan menjadikan subjek di akhir kalimat.Terakhir, kalimat sangat mengerikan merupakan kalimat minor.Tanpa adanya subjek dan predikat, kalimat tersebut sudah memiliki makna.Sama seperti kalimat selamat pagi.

i. Kata ganti

Kata ganti merupakan kata yang digunakan untuk menggantikan subjek yang dituliskan.Tidak ditemukan kata ganti dalam berita (1), (2), (3), (4).Ditemukan kata ganti anda dan mereka dalam berita (5).Kata anda untuk kata ganti orang kedua tunggal, sedangkan mereka sebagai kata ganti orang ketiga jamak yang menjelaskan bahwa penyiar 
radio.Kata ganti di berita (6) ada saya dan dia. Saya merupakan kata ganti orang pertama tunggal dan dia merupakan kata ganti orang ketiga tunggal yang menjelaskan teman penulis.

Kata anda dan beliau menjadi kata ganti dalam berita (18). Anda merupakan kata ganti orang kedua tunggal, sedangkan beliau adalah kata ganti orang ketiga tunggal. Anda bertujuan menyebut pembaca dan beliau bertujuan menyebut dr. Harish Shukla. Berita (19) terdapat dua kata ganti, yaitu saya dan kamu.Saya merupakan penulis yaitu kata ganti orang pertama tunggal dan kamu merupakan kata ganti orang kedua tunggal yang bertujuan menyebut pembaca beita.Berita (20) dan berita (21) tidak menggunakan kata ganti.

\section{j. Leksikon}

Leksikon adalah pemilihan kata atau diksi yang digunakan wartawan dalam menulis berita.Suatu berita dapat dipahami karena terdiri dari kata, kalimat, dan paragraf yang digunakan.namun tidak hanya itu, elemen yang membentuk kata, kalimat, dan paragraf tersebut. Pemakaian kata, kalimat, dan gaya bahasa tertentu tidak hanya semata-mata untuk komunikasi, tetapi juga sebagai strategi penyampaian suatu berita.

Menurut Van Dijk, penyusunan kata dan pemilihan kalimat merupakan hal yang mencaji salah satu fokus bagian yang pantas diteliti dalam sebuah berita. Di bawah ini adalah diksi kesalahan penulisan bahasa Indonesia dalam berita hoaks pada WhatsApp.

\section{1) Afiksasi}

Afiksasi merupakan proses penambahan imbuhan untuk sebuah kata dasar. Terdapat beberapa proses dalam afiksasi, yaitu prefiks (awalan), infiks (sisipan tengah), konfiks (awalan dan akhiran), dan sufiks (akhiran). Pada berita (17) ditemukan kata merubah yang bermakna membuat ubah.Kata merubah merupakan terdiri atas kata dasar ubah yang mendapat awalan meN-.Seharusnya, tidak ditulis dengan kata merubah karena kata dasarnya adalah kata ubab bermakna tukar bukan rubah bermakna hewan sejenis anjing.

Kata ber hati2 pada berita (8) terdiri dari kata hati yang disertai dengan proses reduplikasi dan afiksasi. Proses pertama yaitu kata hati direduplikasi menjadi bati-bati yang bermakna ingat-ingat atau waspada. Proses selanjutnya yaitu terjadi prefiks meN-, sehingga menjadi berbati-hati.Penulisan yang ada pada berita (8) yaitu ber hati2, maka seharusnya penulisan disambung menjadi berhati-hati karena imbuhan tidak bisa memiliki arti jika berdiri sendiri dan tanda reduplikasi adalah dengan dibubuhi tanda hubung bukan angka dua.

Kata di berhentikean pada berita (21) terdiri atas kata dasar henti yang mendapat imbuhan prefiks ber- dan konfiks di- $i$. Seharusnya penulisan di berhentikan ditulis menyambung. Kasus ini ditemukan beberapa kali di berita hoaks.Hal ini terjadi akibat penulis yang kurang mengetahui perbedaan di- sebagai imbuhan dan di sebagai preposisi.Sehingga penulisan kata di berhentikan seharusnya tertulis di berhentikan. Tidak sedikit pula imbuhan yang ditulis sesuai dengan ragam cakapan, seperti kata 
ngambil yang seharusnya ditulis mengambil (berita 8), kata perbatiin yang seharusnya ditulis perbatikan, becanda yang seharusnya bercanda (berita 6), kata balikin yang seharusnya ditulis membalikekan (berita 6), dan kata nerusin yang seharusnya ditulis meneruskan (berita 19).

\section{2) Preposisi}

Preposisi adalah sebuah kata yang biasanya terdapat berada di awal nomina, seperti di, ke, dari, dan dengan. Preposisi di merupakan kata depan yang digunakan sebagai bentuk tanda tempat, misalnya di sini, di mana, di antara, di rumah, dan lain sebagainya. Akan tetapi masih banyak masyarakat awam akan hal ini dikarenakan bentuk terikat di juga dimiliki oleh prefiks atau imbuhan awalan.

Jika kata diluar pada berita (13) diurai, bentuk terikat di yang berada pada kata diluar merupakan di preposisi.Hal itu disimpulkan karena kata luar merupakan kata arah tempat.Diluar juga bukan termasuk kata kerja pasif.Jadi, penulisan kata diluar seharusnya dipisah, menjadi di luar. Seperti data yang diperoleh dalam berita hoaks di Whats App adalah diluar (berita 13 dan berita 8), disekeliling (berita 21), keudara (berita 20), maka kata-kata tersebut seharusnya ditulis secara terpisah.

$\begin{array}{lll}\text { Disekeliling } & \text { menjadi } & \text { di sekeliling } \\ \text { Keudara } & \text { menjadi } & \text { ke udara } \\ \text { Diculik } & \text { menjadi } & \text { diculik }\end{array}$

3) Reduplikasi

Reduplikasi merupakan peristiwa pembentukan kata dengan cara mengulang bentuk dasar, baik secara utuh (benar-benar) maupun sebagian (pepohonan), baik bervariasi fonem atau tidak contohnya bolak-balik, baik berkombinasi dengan afiks atau tidak contohnya motor-motoran. Reduplikasi dalam Kamu Besar Bahasa Indonesia adalah proses perulangan kata atau unsur kata, seperti hutan-hutan. Ditemukan beberapa penulisan reduplikasi dalam berita hoaks pada Whats $A p p$, antara lain: rekan2, ber hati2, dan org2.Kata rekan2 pada berita (10) seharusnya ditulis menjadi rekan-rekan. Kata org2 seharusnya ditulis menjadi orang-orang karena tidak ada makna bagi singkatan kata org. Kedua kata tersebut termasuk ke dalam jenis reduplikasi kata ulang utuh dan murni.

Kata ber hati2 merupakan bagian dari jenis reduplikasi kata ulang berimbuhan. Pasalnya selain kata dasar hati yang diulang, terdapat pula imbuhan prefiks be- . Penulisan kata tersebut pun seharusnya menjadi berhati-hati bukan ber hati2, sebab imbuhan tidak bisa terpisah dari kata dasar.

4) Singkatan/akronim

Singkatan dan akronim adalah dua hal yang berbeda, walaupun keduanya merupakan proses pemendekan. Singkatan merupakan proses menyingkat atau memendekkan beberapa kata menjadi satu kata dalam bentuk huruf atau gabungan 
huruf. Contoh singkatan adalah dari satuan kata Kamus Besar Bahasa Indonesia disingkat menjadi KBBI. Berbeda dengan akronim adalah proses pemendekan yang menggabungkan huruf atau suku kata atau bagian lain yang ditulis dan dilafalkan sebagai sebuah kata. Contoh akronim adalah Fakultas Usuludin, Adab, dan Dakwah menjadi FUAD.

\section{k. Praanggapan}

Kalimat praanggapan pada berita (2) adalah kalimat orang yang terkena gigitan binatang itu secara langsung, umumnya akan wafat setelah 4 jam dari gigitan itu akibat dehidrasi yang sangat dahsyat. Terdapat premis, yaitu akibat debidrasi yang sangat panjang.Kalimat premis ini merupakan praanggapan yang dibangun wartawan agar pembaca percaya, padahal belum ada fakta yang membenarkan anggapan itu.

Ditemukan kalimat praanggapan pada berita (5) yaitu virus masuk ke ponsel anda dan tidak ada yang bisa anda lakukan untuk memperbaikinya.Premis tidak ada yang bisa anda lakukan untuk memperbaikinya merupakan anggapan yang seolah-olah pembaca harus percaya. Berita (6) memberitakan bahwa sumbangan yang diambil dari kembalian receh konsumen minimarket akan ditujukan kepada badan sosial Gereja Kristen Indonesia. Kalimat praanggapan yang ditemukan adalah saya yakin banyak yang tidak tabu hal ini, karena tidak detai bertanya dan kasir tidak memberi tabu.

Kalimat ni magic betul yang memiliki arti ini ajaib sekali merupakan kalimat yang menjadi praanggapan pada berita (7). Kalimat praanggapan sebagai pembentuk arah pemikiran pembaca pada berita (9) adalah kalimat tidak dipublikasi, Pak. Sengaja takut dikonfrontasi.Kalimat tersebut memiliki maksud bahwa "kesengajaan untuk tidak mempublikasi" membuat pembaca beranggapan bahwa berita itu benar, sebab fakta yang sebenarnya disembunyikan.

\section{B. Pola Berita Hoaks}

Pembahasan kedua dari penelitian ini adalah pola berita. Setiap berita pasti memiliki pola yang terdiri dari unsur yang dikenal sebagai istilah $5 \mathrm{~W} 1 \mathrm{H}$. Sebuah berita harus memiliki jawaban dari lima pertanyaan pokok yaitu apa, diap, di mana, kapan, mengapa, dan terakhir bagaimana. Semua unsur pertanyaan tersebut biasa disebut dengan istilah 5 W 1 H dalam jurnalistik. Namun, menurut Kusumaningrat (2016: 129) sekarang tidak hanya cukup dengan $5 \mathrm{~W} 1 \mathrm{H}$ saja, melainkan sebuah berita masih harus ditambah unsur so what atau impilkasi berita tersebut. Berikut ini analisis pola berita hoaks pada Whats $A p p$.

\section{Unsur $a p a$}

Pentingnya unsur apa dalam sebuah berita sama seperti wajibnya unsur tema. Unsur apa dalam sebuah berita adalah titik utama pembahasan. Oleh karena itu, dari semua berita yang diperoleh memiliki unsur apa di dalamnya. Sebagai sampel ada beberapa unsur apa dalam berita hoaks pada Whats $A p$.

Unsur apa pada berita (1) adalah daerah terkena dampak tsunami pada kalimat pibak BMKG sudah memprediksi bahwa nanti malam sekitar jam 1 yang terkena dampak tsunami adalah 
Cilegon, Serang, dan Bandar Lampung. Berita (11) memiliki unsur apa yang dapat ditemukan pada judul berita, yaitu dibutuhkan 50 guru Baca Tulis Alquran. Unsur apa pada berita (13) yaitu inovasi teknologi peternakan yang disebutkan pada lead dalam kalimat ini adalah inovasi terbaru peternakan dengan teknologi cloning blasteran antara sapi dan babi dari ladang peterernakan. Unsur apa pada berita (17) adalah babaya merebus air yang sudab mendidih. Kalimat tersebut menjadi pembahasan utama pada berita (17) dengan disertai penjelasan dan efek samping bahaya merebus air yang sudah mendidih.

\section{Unsur siapa}

Terdapat beberapa berita yang tidak menyebutkan unsur siapa.Berita (5) menggunakan diksi radio sebagai subjek untuk menggantikan unsur siapa pada berita ini.Kata radio dalam kalimat hari ini radio berbicara tentang Whats App Gold, bermakna penyiar radio yang menyiarkan berita tersebut.Dalam berita (13) terdapat sebuah kalimat tanpa subjek yaitu kalimat jadi, apabila membeli daging import pastikan bukan dari negara New Zealand dan Australia.Seharusnya, sebelum kata kerja membeli, terdapat subjek yang melakukan pekerjaan membeli.Dalam kasus berita ini sepertinya ditulis sebagai saran untuk pembaca, sehingga lebih baik menjadi kalimat jadi, apabila anda membeli daging import.

Berita (16) berisi tentang pemberitahuan bahwa tagihan PLN yang biasanya batas maksimal pembayaran pada tanggal 20 setiap bulan, tetapi dimajukan menjadi tanggal 5.Namun, dalam berita ini tidak disebutkan unsur siapa, baik narasumber atau yang diberitakan.Hanya saja pada akhir berita terdapat kalimat permintaan penulis supaya pembaca membagikan pesan tersebut kepada keluarga, tetangga, dan tema-teman.

Ada pula beberapa berita yang menggunakan bentuk kata ganti sebagai unsur siapa.Contoh pada berita (6) dan berita (19) penulis menggunakan kata ganti orang pertama tunggal, yaitu kata saya sebagai unsur siapa yang sedang diceritakan.Berita (6) berisi tentang pengalaman pribadi penulis.Selain berita (5), berita (13), dan berita (16) terdapat unsur siapa dalam teks berita.

\section{Unsur kapan}

Unsur kapan pada berita (1) adalah keterangan waktu nanti malam sekitar jam 1. Keterangan waktu terakhir Desember 2017 dan bulan Januari merupakan unsur kapan pada berita (3).Keterangan tersebut ada pada kalimat pendaftaran terakbir Desember 2017. Seleksi imam bulan Januari di Kemenag pusat.Penjelasan unsur kapan pada berita (4) adalah 6 bulan pada kalimat internet gratis untuk semua operator digunakan dalam 6 bulan.

Terdapat unsur kapan pada berita (5), yaitu kata hari ini pada kalimat hari ini radio berbicara tentang Whats App Gold, sedangkan unsur kapan pada berita (6) adalah kata kemarin pada kalimat kemaren saya belanja di Indomaret.Unsur keterangan waktu pada berita (10) adalah kata belakangan pada kalimat belakangan ini telah terjadi pengiriman paket dari luar negeri maupun dalam negeri ke beberapa alamat yang sengaja disalabkan.Kata belakangan pada kalimat tersebut memiliki makna akhir-akhir ini atau beberapa hari yang lalu.

Keterangan waktu atau unsur kapan pada berita (16) yaitu ada pada kata mulai bulan Maret.Keterangan mulai bulan Maret tersebut menjelaskan bahwa peraturan baru tentang 
waktu pembayaran PLN di tanggal 5 setiap awal bulan, dimulai pada bulan Maret.Terakhir, berita yang memiliki unsur kapan adalah berita (18).Berita (18) memiliki keterangan waktu saat operasi. Kalimat penyumbatan di usus karena konsumsi mie atau spaghetti yang disingkirkan saat dokter melakukan operasi merupakan keterangan waktu yang ditulis sebagai penguat dan penjelasan dari video pada berita tersebut.

\section{Unsur di mana}

Unsur di mana pada berita (1) adalah Cirebgon, Serang, Bandar Lampung pada kalimat pibak BMKG sudah memprediksi bahwa nanti malam sekitar jam 1 yang akan terkena dampak tsunami adalah Cilegon, Serang, dan Bandar Lampung. Keterangan tempat pada berita (3) adalah Amerika, Paris, Jerman, Jepang, Unit Emirat Arab (UEA), Dubai, Korea, dan Qatar. Kalimat yang menjelaskan keterangan tempat tersebut adalah Kemenag membuka kesempatan 150 orang yang masih usia maksimal 30 tahun untuk menjadi imam masjid di berbagai negara, di antaranya Amerika, Paris, Jerman, Jepang, Unit Emirat Arab (UEA), Dubai, Korea, dan Qatar. Berita tersebut mengabarkan informasi lowongan kerja menjadi imam di sejumlah negara.

Keterangan tempat pada berita (15) menjelaskan bahwa acara yang batal didatangi oleh Prabowo di acara fraksi PKS. Berita (18) menjelaskan bahaya konsumsi mie dan spageti karena akan menyebabkan adanya cacing di usus. Hal itu ditujukan dari kalimat yang menjelaskan bahwa operasi pengambilan cacing pada usus dilakukan di Apollo Hospitals. Selanjutnya, unsur di mana atau keterangan tempat pada berita (20) adalah di Palembang. Penggeledahan dan pengeroyokanterhadap warga negara asing asal Cina diketahui terjadi dalam sebuah pabrik di Palembang.Selain berita yang dijelaskan, tidak ditemukan keterangan waktu yang ditulis dalam berita, sehingga berita kurang akurat.

5. Unsur mengapa

Unsur mengapa pada berita (1) adalah daerah Cilegon, Serang dan Bandar lapung harus waspada, karena pihak BMKG sudah memprediksi akan ada tsunami. Berikutnya pada berita (2) yaitu berita yang mewartakan bahaya binatang langka, karena jika terkena gigitan binatang itu, korban bisa meninggal disebabkan dehidrasi panjang.Sedangkan pada berita (3) dan (4) tidak ditemukan alasan atau unsur mengapa.Berita (3) berisi mengenai lowongan pekerjaan imam masjid di luar negeri dan berita (4) berisi tentang hadiah natal dari WhatsApp berupa kuota gratis.

Berita (8) mengabarkan bahwa terdapat kasus penipuan mengatasnamakan Bank BRI.Alasan banyak korban penipuan tersebut adalah kontak yang mengirim sms penipuan tersebut bukan nomor telepon biasa.Namun, kontak itu langsung bertuliskan BRI, sedangkan biasanya kontak dengan tulisan resmi BRI memang berasal resmi dari Bank BRI.Hal itu yang membuat korban percaya dan ahkhirnya tertipu.Unsur mengapa tersebut ada pada kalimat karena pengirimnya terbaca BRI bukan nomor HP, maka dia pun otomatis mengirimkan data via email sesuai permintaan.Karena dia begitu percaya kalau sms itu benar-benar dari BRI.

Berita (20) mengabarkan terjadi pembekukan karyawan WNA asal China di Palembang, tetapi tidak ditemukan alasan yang penyebabkan gal itu terjadi.Berita (21) 
berisi mengenai pengguna mobil pribadi harus berhati-hati saat memarkirkan kendaraannya.Hal itu disebabkan karena terdapat sekelompok orang yang menempelkan stiker berlogo komunis di area parkir, sehingga membuat asumsi bahwa pemilik kendaraan tersebut adalah komunis.

\section{Unsur bagaimana}

Unsur bagaimana adalah unsur yang menjelaskan cara dan perbuatan atau akibat suatu tindakan. Berita (1) mengabarkan bahwa BMKG telah memprediksi tsunami di daerah Cilegon, Serang, dan Bandar Lampung.BMKG menyarankan agar masyarakat untuk waspada dan terus berdoa adalah kalimat yang menjelaskan unsur bagaimana dengan keterangan cara. Berita (2) mengabarkan bahwa terdapat hewan langka yang berbahaya. Cara hewan tersebut membunuh korbannya yaitu dengan menggigit, manusia akan meninggal akibat dehidrasi. Pernyataan tersebut dijelaskan pada kalimat orang yang terkena gigitan binatang itu secara langsung, umumnya akan wafat setelah 4 jam dari gigitan akibat dehirasi panjang.

Berita (3) mengabarkan informasi lowongan pekerjaan menjadi imam masjid di sejumlah negara.Caranya dengan mendaftarkan diri pada ketentuan dan tempat yang sudah disebutkan. Hal itu ada pada kalimat pertama berupa kalau ada teman, saudara, atau siapa pun yang hafal Quran minimal 10 juz, dapat berkomunikasi menggunakan bahasa Inggris dan bahasa Arab, usia maksimal 30 tahun, single, silakan kirim biodata ke emailanas1208@gmail.com.

Berita (4) mengabarkan hadiah natal dari WhatsApp berupakoneksi internet gratis dengan cara mengunjungi tautan yang telah disebutkan. Kalimat yang menunjukkan cara mengambil hadiah tersebut adalah aktifkan layanan gratis ini sekarang https://breakaway.gifts.com/id35GB. Kalimat yang menjelaskan cara pada berita (10) adalah jangan sekali-kali anda mau menerima bingkisan atau paket bila pengirimnya tidak dikenal. Mereka akan datang dengan menyamar sebagai petugas untuk mengambil kembali paket tersebut dengan alasan telah terjadi salah kirim. Kalimat tersebut menjelaskan cara penipuan narkoba melalui salah kirim paket.

\section{Unsur so what}

Menurut Kusumaningrat (2016: 129) berita jaman sekarang tidak hanya cukup dengan unsur $5 \mathrm{~W} 1 \mathrm{H}$ saja, melainkan masih harus ditambah dengan unsur so what. Unsur so what merupakan unsur tentang kedalaman peristiwa dan implikasi sesuatu yang diberitakan.Unsur so what pada berita (1) tidak ada.Berita (2) terdapat unsur so what yaitu kalimat mohon sebarkan, terutama kepada saudara saudari kita yang dekat dengan pohon mangga.

Unsur so what berikutnya, terdapat pada akhir berita (7) berupa kalimat coba kirim ke 4 grup dan battery anda akan penuh 100\%. Kalimat terusin bc (broadcast) ini agar semuanya berhati-hati pada berita (8) adalah unsur so what. Berita (16) juga memiliki unsur so what, yaitu kalimat tolong bantu share kepada keluarga, tetangga, dan temanteman. Kemudian unsur so what pada berita (21) adalah kalimat sebarkan ke grup 
WA.Kalimat-kalimat dalam unsur so what yang ada pada berita hoaks senantiasa menggunakan kalimat imperatif.Kalimat imperatif merupakan kalimat perintah, permintaan, dan larangan. Seperti pada beberapa sampel kalimat berunsur so what yang diawali dengan kata sebarkan, tolong bantu share, mohon bantu kirim, dan coba kirimkan. Adanya kalimat imperatif yang kemudian disertai dengan berita yang seakan benar adanya, akan membuat berta hoaks mudah tersebar.

\section{SIMPULAN}

Hasil penelitian ini dapat disimpulkan bahwa penggunaan diksi dalam berita hoaks pada WhatsApp dalam kurun waktu Desember 2018 sampai Februari 2019 ditemukan penggunaan diksi bahasa asing, bahasa daerah, ragam cakapan, dan singkatan kata yang tidak sesuai KBBI. Berdasarkan 21 berita hoaks pada WhatsApp bulan Desember 2018 sampai Februari 2019 ditemukan pola $5 \mathrm{~W} 1 \mathrm{H}+$ so what. Namun, unsur $5 \mathrm{~W} 1 \mathrm{H}$ tidak semua ditemukan di dalam 21 berita hokas. Ada beberapa berita yang hanya terdiri dari unsur apa, siapa, dan di mana. Ada beberapa berita pula yang tidak dilengkapi hanya salah satu unsur 5 W $1 \mathrm{H}$ tersebut.Namun, mayoritas dari 21 berita hoaks ini memiliki unsur so what berupa kalimat imperatif. Ketidaklengkapan unsur 5 W $1 \mathrm{H}$ dalam berita menyebabkan sebuah berita kurang akurat kebenarannya dan kalimat imperatif sebagai unsur so what itulah penyebab berita yang belum diketahui kebenarannya akan tersebar dengan mudah.

\section{DAFTAR PUSTAKA}

Aslinda, \& Syafyahya, L. (2010). Pengantar Sosiolinguistik. Bandung: PT Refika Aditama.

Barus, S. W. (2010). Jurnalistik; Petunjuk Teknis Menulis Berita. (Y. S. Hayati, Ed.). Penerbit Erlangga.

Brahmana, R. Y. (2013). Pengaruh Penggunaan Celebrity sebagai Endorser terhadap Brand Image Line dan Kakao Talk. Universitas Atma Jaya Yogyakarta. Retrieved from e-journal.uajy.ac.id

Bungin, B. (2012). Penelitian Kualitatif Komunikasi, Ekonomi, Kebijakan Publik, dan Ilmu Sosial Lainnya Edisi Kedua (Kedua). Jakarta: Kencana Prenada Media Group.

Choirroh, L. U. (2017). Tinjauan Hukum Pidana Islam Terbadap Pemberitaan Hoax yang Ketentuannya Diatur dalam Pasal 28 Ayat (1) Undang-Undang Republik Indonesia No. 11 Tabun 2008 Tentang Informasi dan Transaksi Elektronik. Universitas Islam Negeri Sunan Ampel Surabaya. Retrieved from http://digilib.uinsby.ac.id/18774/

Darwin, I. P. J. (2018). Peran Kepolisian dalam Penyidikan Tindak Pidana Penyebaran Berita Bohong (Hoax). Universitas Lampung. Retrieved from digilib.unila.ac.id

Eriyanto. (2012). Analisis W acana Pengantar Analisis Teks Media. Yogyakarta: PT. LkiS Printing Cemerlang.

Gunawan Imam. (2017). Metode Penelitian Kualitatif (Teori dan Praktik) (kelima). Jakarta: PT Bumi Aksara.

Kridalaksana, H. (2009). Kamus Linguistik. Jakarta: P'T. Gramedia Pustaka Utama.

Kurniawan, A. (2017). Metodologi Penelitian Pendidikan. Cirebon: Eduvision.

Kusumaningrat, H., \& Kusumaningrat, P. (2016). Jurnalistik Teori \& Praktik. Bandung: PT Remaja Rosdakarya Offset.

Lauda, S. (2017). Tinjanan Yuridis Sosiologis terhadap Berita Hoax dalam Media Sosial dan Upaya Pencegahannya oleh Polri (Studi di Polda Jatim). Universitas Muhammadiyah Malang. Retrieved from http://eprints.umm.ac.id/37725/ 
Marwan, M. R., \& Ahyad. (2018). Analisis Penyebaran Berita Hoax di Indonesia. Jurnal Ilmiah Informatika Komputer, (0853-8638). Retrieved from ravii.staff.gunadarma.ac.id

Moleong, L. J. (2014). Metodologi Penelitian Kualitatif. Bandung: PT Remaja Rosdakarya Offset.

Pertiwi, W. K. (2018, March). Riset Ungkap Pola Pemakaian Medsos Orang Indonesia. Kompas Tekno, p. $1 . \quad$ Retrieved from https://tekno.kompas.com/read/2018/03/01/10340027/ riset-ungkap-pemakaianmedsos-orang-indonesia

Rosmiati, N. (2017). Analisis Wacana Berita Hoaxpada Media Sosial Studi Analisis Wacana "Aksi Massa Warga Amerika Tuntut Pembubaran FPI" di Facebook. Universitas Pasundan. Retrieved from http:/ / repository.unpas.ac.id

Rusdi, M. (2018). Karena Jurnalisme Bukan Monopoli Wartawan. (Wisnu Prasetya Utama, Ed.). Yogyakarta: Mojok.

Sanjaya, I. (2012). Pemanfaatan "WhatsApp Messenger" sebagai Media Komunikasi pada Remaja Akbir. Universitas Gunadarma Depok, Depok. Retrieved from publication.gunadarma.ac.id

Saure, L., Rembang, M., \& Londa, J. (2018). Analisis Media Sosial WhatsApp Tentang BeritaBerita Hoax. Jurnal Acta Diurna, 7(Vol 7, No 3 (2018)), 1-17. Retrieved from ejournal.unsrat.ac.id

Sudarman, P. (2008). Menulis di Media Massa. Yogyakarta: Pustaka Pelajar.

Sudaryanto. (2015). Metode dan Aneka Analisis Bahasa. Yogyakarta: Duta Wacana University Press.

Sugiono. (2015). Memahami Penelitian Kualitatif. Bandung: Alfabeta.

Suharsimi, A. (2014). Prosedur Penelitian (Suatu Pendekatan Praktik). Jakarta: PT Asdi Mahasatya.

Yunus, S. (2010). . Jurnalistik Terapan. Bogor: Penerbit Ghalia Indonesia.

Zakah, M. N. (2015). Masyarakat Multilingual. Retrieved from repository.widyatama.ac.id. 